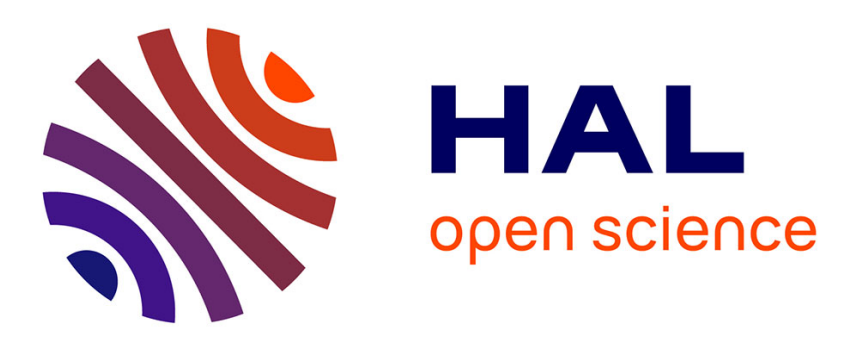

\title{
Who Cares About Ouacil? The Postmortem Itinerary of a Young Border Crosser
}

Carolina Kobelinsky

\section{To cite this version:}

Carolina Kobelinsky. Who Cares About Ouacil? The Postmortem Itinerary of a Young Border Crosser. American Behavioral Scientist, 2020, 64 (4), pp.525-539. 10.1177/0002764219882993 . hal-03284128

\section{HAL Id: hal-03284128 \\ https://hal.science/hal-03284128}

Submitted on 13 Aug 2021

HAL is a multi-disciplinary open access archive for the deposit and dissemination of scientific research documents, whether they are published or not. The documents may come from teaching and research institutions in France or abroad, or from public or private research centers.
L'archive ouverte pluridisciplinaire HAL, est destinée au dépôt et à la diffusion de documents scientifiques de niveau recherche, publiés ou non, émanant des établissements d'enseignement et de recherche français ou étrangers, des laboratoires publics ou privés. 
Kobelinsky, C. (2019) Who cares about Ouacil ? The post-mortem itinerary of a young bordercrosser, American Behavioral Scientist, 64(4): 525-539

The youngsters with whom he shared his daily life knew that his name was Ouacil and that he came from a poor neighborhood in Fez. On-site NGO activists knew that he had been living on the streets of the city for at least a year. The forensic scientists who examined his remains determined that the body was that of a young male, who had died of multiple injuries following a brutal impact. When the deceased was found by the Melilla lighthouse, the police had no clue about his identity.

The starting point of this dead youngster's story, which will be narrated in the following pages, is the moment at which his body was discovered by two young women walking by a cliff in Melilla, a Spanish city in the North of Africa that shares a land border with Morocco and lies beside the Alboran Sea - the westernmost portion of the Mediterranean Sea. The women called the local police. Within an hour or so, the place was crawling with people: police and Guardia Civil officers, ${ }^{1}$ curious locals, and some journalists. The following day, the local newspapers reported the death indicating that he was a "Menor Extranjero No Acompañado (MENA)", an unaccompanied foreign minor. ${ }^{2}$

As a living migrant, this youngster's journey had come to a brutal end. However, movement is coextensive to death and how it is handled (Delaplace, 2015). As a lifeless body, he therefore began a new itinerary, thus creating a new pattern of mobility involving both the living and the dead, forcing them into a form of coordination. By tracing the trajectory of one specific deceased individual, this paper looks at the conflictual interactions that exist between different actors involved in the treatment of deaths at the borders. Inspired by anthropologist Katherine Verdery's (1999) analysis of the political lives of dead bodies, I consider here the dead body found by the lighthouse of Melilla both as a material object and as a symbolic vehicle of political content. In this sense, the dead body becomes an interesting locus for thinking about politics.

This approach sits well with existing scholarship on EU border deaths that, inspired by Foucauldian readings of biopolitics, has examined the policies and practices that lead to a form of government through death (Topak, 2014; Rygiel, 2016; Squire, 2016). It also connects productively with analyses of border deaths as a form of structural violence (Weber \& Pickering 2011), as "crimes of peace" (Albahari, 2015), and with the scholarship interested in exploring the entanglement between technologies and migrants' exposure to "nature" (Schindel, 2016). The choice to focus on a dead body here is also influenced by the literature on contestation over border deaths that take place through grieving (Stierl, 2016) or memorial (Zagaria, 2016) practices.

Drawing on this body of work as a whole, my aim here is to map out the afterlives of the body found by the lighthouse in their multiple dimensions. This will entail examining its itinerary through the different institutions involved in handling it, in both material and symbolic terms, and exploring the diverse ways in which this dead body was considered and understood. ${ }^{3}$ The trajectory that will emerge in the following pages has been pieced together based on multiple conversations and interviews with NGO activists and with young friends of the deceased. I also

\footnotetext{
${ }^{1}$ Spanish law enforcement agency, the Guardia Civil is a military force charged with police duties under the aegis of both the Ministry of the Interior and the Ministry of Defense.

${ }^{2}$ In order to preserve the confidentiality of the data collected with my interlocutors, I am voluntarily omitting any reference to newspaper articles about this death as well as the date on which the body was found.

${ }^{3}$ I follow here the method employed by anthropologist Francisco Ferrándiz (2013) in his study of the afterlives of exhumed bodies of civilians executed under Franco's dictatorship in Spain.
} 
discussed this death with staff at the cemetery and with some inhabitants of Melilla who are not in touch with migrants or those providing them with support but who learnt about the death through the media. Unfortunately, I was not able to gather any specific information from the police. The impossibility of conducting long-term observations with municipal or state officials in charge of managing the dead in Melilla or in Morocco has led me to center my fieldwork on border crossers and, therefore, to focus on the multiple ways in which their travel companions deal with the dead and the disappeared. My material offers a way of grasping the importance of the practices implemented by border crossers themselves when it comes to attempting to identify the bodies found, contacting the family of the deceased, or paying tribute to the dead (Kobelinsky, 2019). The itinerary outlined here is, in this sense, quite different from most of my data as it does not involve border crossers dealing with a deceased companion. Instead, it presents young people being supported by a small group of activists trying to fill the vacuum left by official institutions. It clearly points out, however, the many difficulties that arise in coordinating the actions of everyone involved in handling the dead whenever a body is found. While, on one level, this article discusses a single case, it also draws more broadly on data collected between 2014 and 2018 during ethnographic fieldwork carried out in the Spanish enclave of Melilla and its Moroccan surroundings, as well as on Andalusian coasts and the island of Tenerife, with different actors involved in the treatment of dead migrants found, and among border crossers. ${ }^{4}$

\section{The deceased's name is Ouacil}

Not long after being found by the lighthouse, the body was taken to the morgue, where the forensics team carried out a set of standard examinations in order to determine cause of death and, if possible, to identify the body. His fingerprints did not provide a name. This is usually the case concerning border crossers because, at this point in their journey, they have not yet been registered in any European database. A DNA sample was then collected with a view simply to being stored somewhere because, at the beginning of police inquiries, at least, there is never another sample with which to compare it. ${ }^{5}$ There is no specific procedure, no particular protocol, in place aimed at handling border deaths (e.g. storing data, identifying the deceased, contacting the family, etc.) whether at a national or a European level.

The same day, Laura, a 23-year-old activist working with Prodein - an NGO that defends the rights of unaccompanied migrant minors living on the streets of Melilla, who mostly come from Morocco $^{6}$ - received a phone call. Her name was written on a small piece of paper that the forensics team had found in the dead boy's pocket. Together with her phone number, there were contact details for three other people. The four individuals in question were the women who would go on, a few months later, to be the founding members of Harraga - a small NGO providing further forms of support and assistance, complementary to Prodein's activities with minor migrants. The Guardia Civil officer on the phone asked Laura to go to the Comandancia [Guardia Civil Headquarters] as soon as possible. She immediately contacted her colleagues. The phone call was only a partial surprise. This death was in many ways something of a public

\footnotetext{
${ }^{4}$ This research is currently being carried out with the support of the research program MECMI: Morts en contexte de migration ANR-16-FRQC-0001.

${ }^{5}$ Forensic testing looks for similarities in genetic markers between two biological samples. In order to identify a dead body, forensics teams need the DNA sample of a direct family member so as to compare it with the sample belonging to the deceased.

${ }^{6}$ Prodein - which stands for Pro Derechos de la Infancia - was founded at the end of 1990s by a local teacher and is now the most important NGO supporting migrants in Melilla in terms of its everyday presence on the ground and also in terms of its capacity to publicly denounce the treatment and living conditions of migrants - both minors and adults - at the border.
} 
secret: the people who rubbed shoulders with the youngsters in the streets knew that "something had happened" a few days ago, as the minors were evasive. The activists were all fairly sure that the body was one of "their children".

Laura went to the Comandancia with Marta, whose phone number was also one of those written on the piece of paper in the deceased's pocket. With little preamble, the officers announced to them that the boy had most probably fallen off the cliff. This cliff had recently been surrounded with new metal fences supposed to prevent the youngsters from jumping covertly onto the ferries or scrap iron boats that could take them to the Peninsula. This practice, called riski-a word that most probably derives from the French verb "risquer", to take a risk - consists in climbing the cliffs and the walls surrounding the coast with the help of ropes so as to get to the promenade that ends at the port without being noticed, and then try to sneak onto the vessels without being caught. Riski is very frequent among Moroccan children and young adults. Dozens of youngsters between the ages of 8 or 9 and 18 or 19, living on the streets of Melilla, put their lives at risk almost every night. The President of the autonomous city has stated that, during the first semester of 2017, almost 6,000 minors tried to get onto boats in this way. ${ }^{7}$

The metal barriers near the port are part of a larger landscape of so-called "vallas anti-intrusion" [anti-intrusion wire fences] the contours of which began to develop after Spain joined the EU. ${ }^{8}$ The construction of a fence all along the $12 \mathrm{~km}$ border between Melilla and Morocco began in 1998. At the time, it was one single fence. Subsequently, a second three-meter high barrier was also built in parallel to the first. In 2005, as a response to several attempts by border crossers to jump the double fence - described in the media as "the crisis of the fences" ("crisis de las vallas") - the government decided to raise the fences in question to six meters and build a threedimensional rope, known as the third fence, aimed at preventing any passage between the first and second barrier (APDHA, 2014). During the 2005 attempts, bullets shot from both sides of the border killed at least eleven persons and injured hundreds of others (Migreurop, 2006). Barbed wire can be found all along the border and a sophisticated network of underground cables is linked to electronic noise and motion sensors. This surveillance is completed by night vision video cameras and increased numbers of law enforcement agents from the Gendarmerie royale marocaine and the Guardia Civil constantly patrolling the border. From 2006 onwards, this time in order to respond to what the Spanish media called the "cayucos crisis", the new "Africa Plan" led to agreements being signed with some of the countries that are the point of departure for the boats, i.e. Senegal and Mauritania, so as to reinforce border control cooperation (APDHA, 2007). ${ }^{9}$ Melilla border crossing mainly takes place by land, unlike the strategies developed by border crossers trying to reach Ceuta, which combine attempts to access by sea with attempts to cross the fences. In 2015, in the context of the war in Syria and the socalled "refugee crisis" in Europe, Spain opened an Office to handle asylum claims at the borders in Melilla and Ceuta. At the same time, the Guardia Civil reinforced its surveillance deploying

\footnotetext{
7 http://elfarodemelilla.es/2017/07/05/imbroda-confia-blindar-puerto-frene-efecto-llamada-menores-melilla/ [accessed on 07/07/2017]. https://populartvmelilla.es/2017/07/04/imbroda-valora-que-marruecos-se-concienciedel-problema-de-los-menas/ [accessed on 07/07/2017].

8 In addition to the erection of barbed-wire walls, Spain's entry into the EU and the first Spanish law on immigration in 1985, brought about other dramatic changes to Melilla (but also the enclave of Ceuta). Briefly, it is important to mention the legal implications of the Schengen agreements on the only two land borders between the European and African continents: much of the population of Ceuta and Melilla was in fact of Moroccan origin - and Muslim - but did not have Spanish citizenship or residency rights. After many protests, in 1986 the government approved the naturalization of residents of the enclaves. This process was implemented between 1986 and 1990. For an analysis of the Spanish-Moroccan rebordering since Spain joined the EU in 1986, see Ferrer Gallardo (2008).

9 Another important aspect of the "Africa Plan" concerned migrant readmissions in the signatory countries (APDHA, 2007).
} 
600 officers in Melilla alone and a rotating unit of 180 persons exclusively dedicated to border surveillance (Migreurop \& Gadem, 2015, p. 3). As for Morocco, it has dug a ditch between the first fence and the road in strategic border zones (APDHA, 2016, p. 53).

However, all these sophisticated technologies and fences ${ }^{10}$ clearly do not suffice to prevent the people living in the Gurugu mountain next to the enclave from trying to cross the border between Morocco and Melilla. They do not stop the youngsters from attempting "riski" either, as their "desire for Europe" (Vacchiano, 2014a, p. 60) defies all obstacles. ${ }^{11}$ The mechanisms in place serve only to make these attempts far more difficult and dangerous. These migrants are subjected to a form of perpetual precarity (Butler, 2006), even after death, and their future always includes the possibility of dying drowned, squashed by tons of garbage, chopped up by a boat's propeller, or as a result of injuries caused by barbed wire or by a fall from several meters height. The NGO Caminando Fronteras (2017) recorded 392 deaths at the SpanishMoroccan borders between September 2015 and December 2016. Only 6 of them concerned land border-crossings. ${ }^{12}$ Unlike other border sites, few dead bodies are found around the enclave of Melilla. Death is, however, omnipresent both as a specter and a concrete reality frequently mentioned by all my interlocutors in the region (Kobelinsky, 2017).

At the Guardia Civil Headquarters, the officers asked Laura and Marta to help in the identification procedure by showing them some pictures. They preferred not to show them the body itself as it had been severely damaged by the sea and seagulls. The forensics officers estimated that the boy must have died at least 72 hours before his body was found. Laura and Marta agreed to help. Sitting in a small office, they began looking at the pictures taken at the morgue. The two of them felt uncomfortable, Laura remembered that she had to try to stop her hands from shaking. They soon began to think they would be of no help as the dead boy in the pictures had blue eyes and none of the children they worked with had blue eyes. The officers explained to them that they should not take into account eye color as it changes as a result of the decomposition process. They continued to look at the pictures. As Marta recounted:

"I then looked at the kid's lips, the lips were very particular, I knew those lips... Ouacil's lips. I took my phone, because we had taken lots of pictures of the concert on the Friday night [which they attended with many of the children] and we saw that he was wearing the same clothes as in the police pictures" (interview, Melilla, 05/29/2016).

Marta and Laura then looked at other details and were able to confirm that the dead body was that of Ouacil. They signed some papers and eventually left the Comandancia.

Ouacil, like many other youngsters who die of hypothermia trying to swim to the boat that could take them to the Peninsula, had arrived in Melilla from Morocco by crossing one of the border posts. They usually arrive very early at the border to cross the first - Moroccan - post and then wait in the space separating the Moroccan from the Spanish post. There, they are usually in the zone where the porteadoras (women carriers) return from Melilla carrying goods and try to sneak in in the opposite direction. Once on Spanish land, if the police arrest them, unaccompanied minors are entitled to city guardianship (tutela) via its Well-being Office

\footnotetext{
${ }^{10}$ On the "industry" surrounding the politics of border control, see Rodier (2012) and Andersson (2014).

${ }^{11}$ Drawing on more than a decade of research on the mobility of unaccompanied minors' mainly across the Maghreb and Europe, Vacchiano (2014a, 2014b) considers this migration as an expression of globally hegemonic forms of "being-in-the-world". The subjective construction of youths" "desire for Europe" is to be understood as a request to participate in the contemporary world and as an aspiration to modernity.

${ }^{12}$ In face of the lack of official statistics on border deaths, I looked at the figures produced by Caminando Fronteras. In its report, the NGO compiled analysis of the alerts - phone calls or messages - received by migrant communities of sub-Saharan Africa between September 2015 and December 2016. In 309 alerts received from the sea, 388 people died and in 23 alerts relating to attempts to cross the enclaves' fences, 6 people died (Caminando Fronteras, 2017: 39)
} 
[Consejería de Bienestar] - after their age has been determined and their status as MENA ${ }^{13}$ confirmed. They are then sent to "La Purísima", a center for minors located in a former military fort. This, however, is a place from which many of the children try to escape. The living conditions and the daily treatment there are, as one of them put it, "as awful as you can imagine, you are not treated as a kid. You are not even treated as a person." The numerous stories of humiliation and bad treatment in the center ${ }^{14}$ explain, at least partially, why many choose instead to sleep on the streets.

Ouacil lived in extremely precarious conditions and was stigmatized daily by a large portion of the local population, who consider the youngsters living on the streets to be responsible for all the city's problems. When he died, Ouacil had no longer been under the guardianship of the city for six months because the administration considered he had reached the age of 18 . The Consejería de Bienestar never delivered any public statement concerning his death (or concerning his life under the aegis of the city). The absence of public discourse has contributed to silencing this youngster's death en route to "the real Europe" - as many of my interlocutors refer to the European continent - or at least to disentangling it from any political meaning. Moreover, as the days went by, the newspapers that had initially published the news of the death of a "MENA" started instead referring to the deceased, in their very short articles on the matter, as an "illegal immigrant" or an "adult man", thereby removing the possibility of the autonomous city being held responsible. And indeed, this responsibility could have been invoked insofar as Ouacil was obviously living on the streets only a few months after having theoretically been under the protection of the city. ${ }^{15}$

\section{Mourning Ouacil}

Once out of the Comandancia, Laura and Marta met Ana, another activist. After a brief conversation, they agreed that Ouacil's family had to be informed. "It is the least we can do, it is what you'd want for yourself, isn't it? For your family to know”, explained Marta. ${ }^{16}$

They knew the boy was born in Fez and that his family lived in the same neighborhood as Mounsif, another child also living on the streets of Melilla. During a long interview, Ana remembered: "We took the car and started driving around, looking for Mounsif." They finally found him near the CETI [Centro de Estancia Temporal para Inmigrantes], the shelter where adult migrants wait to be sent to the Peninsula. ${ }^{17}$ They announced Ouacil's death to Mounsif

\footnotetext{
${ }^{13}$ Article 189 of the Royal Decree 557/2011 of April 20th approving the Regulation of the Organic Law 4/2000 on rights and liberties of foreigners in Spain and their social integration, defines a MENA as any "foreigner under eighteen who arrives in Spanish territory without an adult who is legally or customarily responsible for him, considering the risk of lack of protection for that minor, if the responsible adult has not taken care of him, as for any foreign minor who finds himself in this situation once in Spain." This category has emerged progressively within the EU context during the 1990s (Senovilla Hernández, 2014).

${ }^{14}$ Many NGOs have denounced ill treatment in La Purísima. See, for instance, the article by Néstor Cenizo, "La Purísima, el lugar del que huyen los niños en Melilla", El Diario.es, August 4th, 2016. http://www.eldiario.es/desalambre/Purisima-lugar-huyen-ninos_0_537197121.html [accessed on 07/07/2017].

${ }_{15}$ The activists affirmed the boy had been living on the streets for at least a year at the time of his death.

${ }^{16}$ I have examined elsewhere the fact that adult border-crossers mainly coming from West Africa agree, in the same vein, that announcing the death to the family is crucial as it prevents the deceased from disappearing without leaving any trace (Kobelinsky, 2017).

17 The CETI opened in 1999, at the same time as the fences were set up. It is conceived as a reception center and, according to the webpage of the Ministry of Labor, Migration, and Social Security, it provides "basic social services to the community of immigrants and asylum seekers who arrive (...) while they comply with the identification procedures and medical check-ups prior to any decision (...) according to their administrative situation in Spain”. All unauthorized migrants over 18 arriving in the enclave are sent to the CETI before being transferred to the Iberian Peninsula. Once on the other side of the Mediterranean Sea, they
} 
and asked him to help them contact the family. The 15-year-old boy took Ana's mobile phone and called his father for help. The man said he could find Ouacil's father very easily. A couple of hours later, the activists had obtained the contact details of Ouacil's family in Fez and decided to provide them to the police.

At this time, Marta, Laura, and Ana - along with Clara, who was not in town when Ouacil's body was found - were involved in setting up a range of activities with the youngsters on the streets under the aegis of the NGO Prodein. The four of them were aged between 23 and 28 and had arrived in Melilla from different Spanish regions to complete their diploma in Social Education at the local branch of the Universidad de Granada. After some months in the city, shocked by the situation of the children living on the streets, putting their lives in jeopardy through "riski" and being criminalized by locals who identified them as delinquents, they decided to approach Prodein. The four women started spending time on the streets on a daily basis. Walking around in the areas the youngsters usually frequented but also "patrolling" the streets by car early in the night - before they would go and attempt riski.

The activists engaged in relationships they referred to as "pedagogical friendships" 18 with many of the boys. These are relationships founded on a form of care based on proximity to each individual and on analysis of the reality of "migrant children" living on the streets more broadly. In this sense, they constantly denounced - both in their everyday practices and in written texts (an annual report and occasional press releases) - the situations of injustice experienced by the youngsters. The activists defended these children's "right to play", that is to say that by setting up children's activities, they allowed them to enjoy their condition as children, setting aside survival on the streets. However, the activists also took on many different roles at the same time: they were sometimes nurses, when they treated superficial wounds caused by bad hygiene conditions or when they took the children to hospital if they would not be admitted to the emergency room should they arrive alone. They were also important guides in administrative matters, when one of the youngsters had the chance to have his immigration status regularized for example. But the activity that all four of them considered to be most important was the football workshop they organized three times a week in a central square of the city. While playing matches and sharing candy, they would keep an eye on the youngsters' general state of health and also on the degree to which they were using various drugs. At the same time, by organizing these games right in the heart of Melilla, they were also trying to make the youngsters' condition as children plain to see. In Ana's words, the "struggle" was "to show, to put in front of everyone's eyes, the fact they are kids like any others", that is to say, children who need protection. ${ }^{19}$

can be confined in a detention facility in order to organize their deportation from the national territory or be hosted by an NGO providing sanitary, social and legal follow-up for some months. http://www.mitramiss.gob.es/es/Guia/texto/guia_15/contenidos/guia_15_37_3.htm [accessed on $12 / 10 / 2018]$.

${ }^{18}$ I had the chance to discuss their sources of inspiration with Marta and Ana on several occasions. This "pedagogical friendship", based on creating the conditions for a relationship of trust and care, draws on the work of Enrique Martínez Reguera and Enrique de Castro. Enrique Martínez Reguera is a key reference in pedagogy related to youths in marginal situations. He was one of the founders of the Escuela de Marginación de Madrid, an institution dedicated to training people working with minors in marginal situations. Enrique de Castro was a Catholic priest who worked for forty years with different collectives in marginal situations around Vallecas, southeast of Madrid.

${ }^{19}$ After more than a year working as part of NGO Prodein, the four women decided to found another, specific, NGO named Harraga. This neologism, deriving from Arabic but written in the Latin alphabet, was a term they had often heard used by the children and that is used in the Maghreb to refer to those who "burn" the borders, leaving their home without passport or visas, looking for a better life. Harraga does not receive any kind of public funding and its only support comes from private donors. Several months after its inception, the NGO opened up to 
The very day Ouacil's body was identified, the news about his death began to spread among the youngsters. Some of them, who probably already knew about it, preferred not to say anything for fear of the police. Or at least this is what I surmised from a conversation with one of them many months later. Ana remembered that that afternoon Laura, Marta, and herself had been sad and worried about the young boys: "We wanted to say goodbye to Ouacil and to work through the mourning process with the kids [niños], they are alone and have no family here." Without much forward planning, they decided to organize a gathering. They went out on the streets, telling the youngsters they knew to meet where Ouacil had died.

They arrived at the lighthouse carrying large white sheets and paintings as an invitation to the children to express themselves, in case they couldn't find the words. At first, there were not many people. Two boys started drawing and writing about their sadness and many others then arrived. "There were more than 50 people, the news spread and the kids kept coming", explained a young Moroccan who had known Ouacil very well and who participated in the gathering. They hung the paintings on the fences and observed a minute's silence, with the local police and Guardia Civil patrols stationed nearby. For most of the people who participated, this improvised get-together made it possible to share their pain and to "say goodbye" to Ouacil, as one 15-year-old boy told me. Almost a year later, Laura reminisced: "It was really moving, we shared our sorrow, we were together, we were all with Ouacil. Somehow, we felt a little better. A little less bad." The gathering had effects on those who participated because it afforded the possibility of collective mourning and a way of staking a claim to a form of collective life. By giving visibility to this death, the meeting transformed the participants' pain into a way of denouncing how the authorities abandon those they are supposed to protect and literally leave them to die. It also exposed the lethal nature of the borders, which, in their material reality, are the active cause of deaths. In this sense, the gathering could be said to be a form of "griefactivism" (Stierl, 2016) acknowledged as such by its organizers, which also had effects on passersby and on people who heard about it after the event, through hearsay or on the news. For a fleeting moment, at the very least, these people were unable to completely ignore border deaths. Moreover, though, the meeting did not only politicize the participants' actions and emotions, it also politicized the deceased youngster himself. The gathering enrolled him in the power relations that face the living and revealed the violence to which all (living and dead) migrants are exposed. Now endowed with a "political life" (Verdery, 1999), Ouacil took part in defending his companions who were still alive. Through him, all the unaccompanied foreign minors living on the streets of the city and endangering their lives every night through riski were made visible and portrayed in another light, far from the usual depictions conflating them with drug addicts, thieves, or threats to public order. The ceremony by the lighthouse also had unexpected effects for the organizers. A month later, Prodein received a complaint and had to pay a 1,500 euro fine for organizing a "subversive meeting" and for "promoting acts of vandalism".

Ouacil's death hit the youngsters hard: they had all known him. After the ceremony by the lighthouse, many of them "shut themselves away in their grief or in fear", as one activist put it. During a long conversation, Ana remembered "there were hard times, so hard that the kids wouldn't go down to the port, they were very afraid, most of all the little ones, they didn't say much but they were totally scared." And Marta added: "yes, those days glue consumption rose a thousand times over, as you can imagine". "It's that the death is very close", summed up Hamza, a young Moroccan who knew Ouacil well.

volunteers - mainly students in social education at the local university. However, the important decisions taken by Harraga are made by the four founding members. 


\section{Managing the body}

A week after the discovery of the body by the lighthouse, Ouacil's father came from Fez to Melilla with one of his uncle's and one of his older brothers. Mounsif's father had announced Ouacil's death to his family and the Spanish police had subsequently contacted them. "Really poor, the father, really poor, it was clear that he had worn his best clothes to come", recalled Marta. Ouacil's remains were still at the morgue. The police authorities were waiting for the relatives at the border post in order to sort out the red tape around their entry to the city. This could only occur during the day and they had to be accompanied by a police officer at all times. They were not authorized to remain in Melilla at night and had to sleep on the other side of the border, in Beni Enzar, at a distant acquaintance's home.

Ana, Laura, and Marta learnt from Mounsif that they had arrived and went to the border in order to introduce themselves and tell them they had started raising money to allow "Ouacil to rest in peace in Fez", in other words, to allow his remains to be repatriated. The activists had activated their network all over the country: they had circulated a note asking for donors among their friends, anticipating what they thought the family would prefer to happen to the body. They had also contacted the Islamic Commission in Melilla to find out what the conditions for transport were and what different alternatives were possible. Thanks to an acquaintance, they had also got in contact with a man who owned an ambulance and could transport the corpse.

However, they were unable to speak directly to the family as they were forbidden by the police from approaching them. Given that the relatives were always escorted by law enforcement agents, it was also difficult for the youngsters who had known Ouacil to approach them. The activists tried to explain to the police officers why they wanted to introduce themselves to the family, but the officers argued that they were too busy to waste their time talking to them. The relationship between these women and the police - and more broadly the city authorities - was far from cordial. The characteristics ascribed to the unaccompanied minors living on the streets were also conferred upon these women and as such they were perceived as threatening and sometimes criminalized. They frequently received police "visits" in their home - Ana, Laura, and Marta lived together in a flat in the city center - to check that they were not housing undocumented migrants, that their rental contract was in order, and that they were not selling illegal products.

Mounsif was eventually able to talk to Ouacil's brother. He learnt that the family had confirmed the identity of the body found by the lighthouse. He also found out that the police had informed Ouacil's relatives that the activists were in fact journalists and were not trustworthy. They had advised them more generally not to talk to anyone in Melilla. Armed with this knowledge, they decided to try talking to the family again on the second day of their visit to the city. They went to the border post early in the morning to intercept them at their arrival. But once again, they were unsuccessful. Ouacil's relatives left Melilla that same day and the activists therefore decided to return the money that had been collected to the donors.

A week later, Ouacil's father, uncle, and brother returned for the funeral together with his mother and some other relatives. The burial was a private family affair that took place at the Muslim Cemetery but with a police vehicle parked at the entrance, probably because the relatives were not entitled to remain in the city. Many youngsters waited until the ceremony was over and nobody was around to get into the cemetery and honor their friend. Almost a year after the burial, a boy told me that Ouacil's family would have wanted to repatriate the body but could not do so because they had no money. The City does not cover such expenses and the family was never aware that funds had been raised for this purpose. 


\section{On grievability}

The post-mortem itinerary retraced above is not ordinary compared to all my data on the Spanish-Moroccan borders. This is firstly due to the young age of the deceased. Most of the trajectories I have followed and stories I have gathered regarding deceased migrants concern adults. Another reason for the specificity of the itinerary outlined here is that, while he was alive, Ouacil spent time with a group of activists in the city who were able to provide information to the police without fearing for their safety or their own future, as is the case for border crossers. Many of my interlocutors - mostly adults - shared with me their fear of ending up in prison should they go to the police - either in Spain or in Morocco - in order to provide information about a dead body that has been found. This does not, however, mean that travel companions do not participate in attempts to identify the dead. On the contrary, they are very active on social networks when it comes to circulating pictures, searching for information about relatives, etc. The third reason that means this itinerary is not that usual is that the body was identified. Most of the time, the corpses found at the borders remain unknown and are placed in niches in local cemeteries. A basic plaque often indicates the date and perhaps the nationality of the deceased. Sometimes, the gravedigger will inscribe "Immigrant" or "Unknown Immigrant" on the fresh cement. The fourth and final reason is that Ouacil was a national of Morocco, which is a neighboring country. This geographical proximity facilitated interactions with the family, making it possible for them to come to Melilla, and would also have simplified the repatriation had this occurred.

Despite these specificities, which make this an extraordinary case in some respects, I nevertheless chose to examine Ouacil's post mortem itinerary because, due to how simple and linear it is in comparison with other cases, it sheds productive light on the problematic interactions that exist between municipal institutions, civil society groups, relatives, and migrants themselves, all of whom are involved in managing the dead. The itinerary outlined here shows the very rudimentary dimension of this management, which depends more on makeshift solutions put together by specific individuals that on any institutionalized protocol aimed at identifying bodies, contacting relatives, and knowing (or even following) their wishes concerning the fate of the remains. It would have been reasonable to imagine that the activists' involvement would facilitate the process of dealing with the dead - they are Spanish, know the intricacies of local bureaucracy, and have many social resources on which to rely. While this was no doubt true when it came to identifying the body, it was not the case regarding the body's final resting place and it being returned to his family. The fact it was impossible for the activists to have any contact with Ouacil's relatives is most probably due to their "bad" relations with the local authorities and police. It is possible that, had other larger NGOs at a national level put pressure on the ground at this very moment, the authorities might have reacted differently. At the same time, the lack of government concern in this case is undoubtedly related to the fact that the Moroccan youngsters living on the streets of Melilla are discredited and rejected.

Commenting on the death of another boy near the port of the city in March 2016, the head of the Consejeria de Bienestar stated: "It is not the first time that a minor drowns, and it will not be the last." 20 These words make it clear that the deaths of unaccompanied minor migrants in Melilla are not "grievable", and that their lives are expendable. In her examination of the value of the lives and deaths of those who are subjected to a form of perpetual precarity, Judith Butler (2006, p. 15) asks "what counts as a livable life and a grievable death?" Alive, men, women, and children trying to get to Europe are considered dispensable beings, whose lives are not worth safeguarding and valuing. In the case of the youngsters living on the streets, they are all

${ }^{20}$ https://www.lamarea.com/2018/01/10/los-muertos-que-el-gobierno-oculta-hasta-a-sus-familias/ [accessed on 06/26/2018]. 
the more expendable as they are considered figures of evil. Dead, they are still considered and treated as undervalued, marginal individuals, whose very existence is neglected and silenced. The lack of a standardized procedure to deal with the dead at the borders, as well as the absence of official statistics concerning these deaths ${ }^{21}$, could be viewed as a way of contributing to their invisibilization.

The detailed description of the itinerary of one specific body found at a border affords the possibility of understanding the multiple meanings that the deceased can be ascribed, highlighting the stark contrast between, on the one hand, a politics of erasing these deaths, and practices of care and attention aimed, on the contrary, at making them visible and showing that they matter. Paraphrasing Verdery (1999, p. 28), Ouacil's dead body was only meaningful here because of how the dead person's (non)importance was construed by the various actors involved in its treatment. The different practices - of care, attention, concealment, and indifference - around this body therefore offered the possibility for a micro-level analysis of the politics of meaning and emotion surrounding migration. Such a politics entail a particular "distribution of the sensible". By this concept, Jacques Rancière (2004) refers to the way in which modes of participation in a common social world are determined by establishing possible modes of perception. In this sense, the distribution of the sensible establishes divisions between what is visible and invisible, "sayable" and "unsayable", audible and inaudible. The approach adopted in this article, centered on the deceased - the spatial trajectory of his body, the actors gravitating around it, Ouacil's afterlife - captures this particular division between the visible and the invisible that lies at the core of contemporary government of migration as it is deployed daily and surreptitiously around the practical management of the dead in border zones.

Since his death, from time to time Ouacil "visits" Hamza and other friends in their dreams. It is his way of resisting oblivion and of being grieved.

\section{References}

Albahari, M. (2015). Crimes of Peace. Mediterranean Migrations at the World's Deadliest Border. Philadelphia: University of Pennsylvania Press.

Andersson, R. (2014). Illegality Inc. Clandestine Migration and the Business of Bordering Europe. Berkeley: University of California Press.

APDHA (2016). Derechos humanos en la frontera sur, Sevilla, Asociación Pro Derechos Humanos de Andalucía. URL: http://www.apdha.org/media/informe-frontera-sur-2016web.pdf [accessed on 06/27/2018].

APDHA (2014). Derechos humanos en la frontera sur, Sevilla, Asociación Pro Derechos Humanos de Andalucía. URL: http://www.apdha.org/media/frontera_sur_2014_web.pdf [accessed on 06/27/2018].

Butler, J. (2006[2004]). Precarious Life. The Powers of Mourning and Violence. New York: Verso.

Caminando Fronteras (2017). Tras la frontera. URL: https://caminandofronteras.files.wordpress.com/2017/05/ccf-itlf-arte-final-web.pdf [accessed on $12 / 10 / 2018]$.

\footnotetext{
${ }^{21}$ For a discussion on border deaths statistics, see Heller \& Pécoud (2018), Tazzioli (2015).
} 
Delaplace, G. (2015). Introduction : incertitudes morales, régimes de visibilité et vitesse de circulation des morts, Delaplace, G. \& F. Valentin (eds.) Le funéraire : mémoire, protocoles, monuments. Paris : De Boccard, 11-23.

Ferrándiz, F. (2013). Exhuming the defeated: Civil War mass graves in 21st century Spain, American Ethnologist, 40(1), 38-54.

Ferrer Gallardo, X. (2008). The Spanish-Moroccan Border Complex: Processes of Geopolitical, Functional and Symbolic Rebordering. Political Geography, 27, 301-321.

Heller, C. \& Pécoud, A. (2018). Counting migrants' deaths at the border: From civil society counter-statistics to (inter)governmental recuperation. IMI Working Paper Series, 143, 1-20.

Kobelinsky, C. (2017). Exister au risque de disparaitre. Récits sur la mort pendant la traversée vers l'Europe. Revue européenne des migrations internationales, 33(2-3), 115-131.

Kobelinsky, C. (2019). Les traces des morts. Gestion des corps retrouvés et traitement des corps absents à la frontière hispano-marocaine. Critique Internationale, xxxx.

Rancière, J. (2004). The Politics of Aesthetics. The Distribution of the Sensible. London \& New York: Continuum Impacts

Rodier, C. (2012). Xénophobie business. A quoi servent les contrôles migratoires ? Paris: La Découverte.

Rygiel, K. (2016). Dying to live: Migrant deaths and citizenship politics along European borders: Transgressions, disruptions and mobilizations. Citizenship Studies, 20(5), 545-560.

Senovilla Hernández, D. (2014). Analyse d'une catégorie juridique récente : le mineur étranger non accompagné, séparé ou isolé. Revue européenne des migrations internationales, 30/1, 17 34.

Schindel, E. (2016). Bare Life at the European Borders. Entanglements of Technology, Society and Nature. Journal of Borderlands Studies, 31(2), 219-234.

Squire, V. (2016). Governing Migration Through Death in Europe and the US. Identification, Burial and the Crisis of Modern Humanism. European Journal of International Relations, 23 (3): 513-532.

Stierl, M. (2016). Contestations in Death. The Role of Grief in Migration Struggles, Citizenship Studies, 20(2), 173-191.

Tazzioli, M. (2015). The politics of counting and the scene of rescue: Border deaths in the Mediterranean. Radical Philosophy, 192, 2-6.

Topak, O. (2014). The biopolitical border in practice: Surveillance and death at the GreekTurkey borderzone. Society and Space, 32, 815-833.

Vacchiano, F. (2014a). À la recherche d'une citoyenneté globale. L'expérience des adolescents migrants en Europe. Revue européenne des migrations internationales, 30(1), 59- 81.

Vacchiano, F. (2014b). Beyond borders and limits: Moroccan migrating adolescents between desire, vulnerability and risk. Saúde e Sociedade, 23(1), 1-12.

Verdery, K. (1999). The Political Lives of Dead Bodies. Reburial and Postsocialist Change. Chichester: Columbia University Press.

Weber, L. \& Pickering, S. (2011). Globalization and Borders: Death at the Global Frontier. Basingstoke \& New-York: Palgrave Macmillan. 
Zagaria, V. (2016). Vita e morte alla Porta d'Europa. Riflessioni sulle tombe dei morti di frontiera nella provincia di Agrigento. Intrasformazione, 5(1), 80-100. 